ABDIMAS: Jurnal Pengabdian Masyarakat Universitas Merdeka Malang
Vol.5(3) November 2020,312-318
p-ISSN: 2721-138X | e-ISSN: 2548-7159
http://jurnal.unmer.ac.id/index.php/jpkm

\title{
Meningkatkan Kemampuan Problem Solving Siswa-Siswi SMA Negeri 7 Semarang melalui Bebras Challenge
}

\author{
Liya Umaroh, Novita Kurnia Ningrum, Titien Suhartini Sukamto
}

Departemen Teknik Informatika, Fakultas IImu Komputer, Universitas Dian Nuswantoro, J. Imam Bonjol No.207, Semarang, 50131, Indonesia

\section{ARTICLE INFO: \\ Received: 2020-04-10 Revised: 2020-06-20 Accepted: 2020-09-02}

\section{Keywords:}

Problem solving; Students; Way of thinking

\begin{abstract}
Associative and directed thinking are two important ways when a person thinks of an idea that is directly continuous with the emergence of other ideas and in the end has been coherently determined the direction of problem solving. Things like that are often experienced by everyone, especially high school students. The various school assignments they have to do, socialize with school friends, and interact with family at home are so complex that the problems exist that require students to think critically and solve problems well. Bebras Challenge is one of the contests that directs participants, especially high school level, to practice problem solving skills through learning activities by working on problems. The Bebras Challenge activity was attended by various levels of schools, from the lowest levels of Elementary School to Senior High School. SMA Negeri 7 Semarang was one of the participants who took part in the Bebras Challenge, students were encouraged to practice problem solving skills in the contest. The end result of the Bebras Challenge activity is to improve students' abilities in dealing with various problems, one of which is that in the field of subjects in schools, they are able to answer questions in different ways and have the same final result.
\end{abstract}

(C) 2020 Published by University of Merdeka Malang. This is an open access article distributed under the CC BY-SA 4.0 license (https://creativecommons.org/licenses/by-sa/4.0/)

How to cite: Umaroh, L., Ningrum, N. K., Sukamto, T. S. (2020). Meningkatkan Kemampuan Problem Solving Siswa-Siswi SMA Negeri 7 Semarang melalui Bebras Challenge. Abdimas: Jurnal Pengabdian Masyarakat Universitas Merdeka Malang, 5(3), 312-318. https://doi.org/10.26905/abdimas.v5i3.4320

\section{PENDAHULUAN}

Problem solving memiliki pengertian tentang cara berpikir untuk menyelesaikan permasalahan yang muncul dengan upaya memilih salah satu dari beberapa alternatif jawaban yang mendekati kebenaran dari sebuah masalah. Empat faktor penting dalam problem solving, yaitu motivasi, kepercayaan, emosi dan kebiasaan. Motivasi sebagai dasar dari sebuah pemecahan masalah, keinginan untuk segera menyelesaikan masalah dan percaya bahwa masalah akan segera terselesaikan bersamaan dengan cara berpikir 
asosiatif dan terarah (Maulidya, 2018). Soft skill problem solving wajib dimiliki oleh setiap orang khususnya siswa-siswi sekolah menengah atas. M ereka harus mampu menyiapkan mental dan cara mengatasi berbagai permasalahan untuk menghadapi dunia kerja kelak.

Soft skill problem solving seseorang dapat ditingkatkan dengan beberapa cara yaitu: (1) Berani mengubah pola pikir, memang pada awalnya sangat sulit dilakukan sebab membutuhkan waktu yang sangat lama, kebiasaan menghindari masalah diubah menjadi pola baru, masalah adalah tantangan hidup; (2) Identifikasi masalah, tidak hanya sekedar mencari tahu dari mana sumber masalah tetapi mampu menggali secara logis akar dari permasalahan yang muncul; (3) Menerapkan metode mind mapping, memetakkan jenis permasalah yang ada dengan memikirkan kemungkinan pemecahannya; dan (4) Mengembangkan komunikasi, hal ini sangat penting dilakukan agar solusi tepat sasaran (Mayer,1992).

Sistem pendidikan di tingkat dasar hingga menengah perlu untuk dievaluasi dan dibandingkan secara global. Salah satu cara untuk mengevaluasinya adalah dengan memanfaatkan hasil survey yang dilakukan oleh Organisation for Economic Co-operation and Development (OECD), melalui test PISA (Programme for International Student Assessment) (Ayub \& Karnalim, 2017). Test dilakukan pada siswa berusia 15 tahun untuk mengukur kemampuan dalam bidang membaca, menulis dan aritmatika, serta sains.

Salah satu penyebabnya adalah pola pendidikan yang diajarkan di sekolah usia dini dan sekolah dasar belum mengajak siswa untuk terlibat langsung dalam masalah dan memberikan ruang bagi siswa untuk mengambil tindakan sesuai dengan pola pikir mereka untuk mengambil keputusan berdasarkan masalah yang mereka hadapi. Oleh karenanya diperlukan upaya untuk mengajarkan siswa untuk terbiasa berpkir untuk bertindak solutif ketika menghadapi masalah dengan mengasah kemampuan problem solving sedini mungkin.

Arifin et al. (2019) dalam penelitiannya mengangkat tiga buah permasalahan tentang problem solving, yaitu: (1) Mendeskripsikan keefektivan model pembelajaran berbasis masalah; (2) Mendeskripsikan tindak lanjut dari pemecahan masalah; dan (3) Mendeskripsikan pola pemecahan masalah secara kognitif. Adapun populasi yang diambil adalah siswa kelas XI dengan metode pengambilan data menggunakan uji beda rata-rata menggunakan statistik. Hasil akhir dari kesimpulannya adalah adanya peningkatan soft skill problem solving dengan pendekatan kognitif.

Sebagai soft skill yang berkaitan dengan problem solving, CT or computational thinking merupakan bagian yang tidak dapat dipisahkan dan berkaitan erat dalam memahami perilaku manusia dengan mengambil konsep dasar dari ilmu komputer (Wing, 2016). Kemampuan berpikir secara komputasi sangat baik jika ditambahkan pada kemampuan analitis seseorang, kemampuan membaca, menulis dan aritmatika. CT menggunakan proses abstraksi dan dekomposisi saat digunakan untuk memecahkan masalah (problem solving), dimana tahapannya adalah: (1) Masalah dibagi ke dalam subtask yang lebih mudah; (2) Direpresentasikan/digambarkan; (3) Menggunakan dan menginterpretasikan data; (4) Menyusun algoritma yang dapat dieksekusi oleh mesin; dan (5) Mengevaluasi aspek efisiensi serta estetika (Chen et al., 2017). Kemampuan problem solving merupakan salah satu keahlian yang tidak dapat digantikan oleh mesin, sehingga sangat dibutuhkan dalam menghadapi kompetisi global dunia bisnis dan industri. Melihat pada test PISA yang dilakukan kepada siswa berusia 15 tahun, maka kemampuan CT ini akan lebih baik jika diterapkan sejak dini (Basogain et al., 2018). 
ABDIMAS: Jurnal Pengabdian Masyarakat Universitas Merdeka Malang

Volume 5, No 3, November 2020: 312-318

\section{METODE}

\section{Analisis Masalah}

Berdasarkan latar belakang permasalah pada bab pendahuluan maka masalah yang muncul adalah: (1) Kemampuan siswa sebagian besar masih dibawah rata-rata nilai Programme for International Student Assesment (PISA) dari seluruh dunia; (2) Kurangnya pembelajaran berbasis problem solving yang diberikan pada saat di sekolah khususnya di sekolah SMAN 7 Semarang sebagai mitra pelaksanaan pengabdian kepada masyarakat; dan (3) Minimnya pelatihan pada guru dalam menerapkan konsep problem solving yang diimplementasikan dalam kegiatan belajar mengajar.

\section{Analisa Kebutuhan}

Sejalan dengan pemaparan analisa masalah, maka secara umum yang dibutuhkan adalah: (1) Mengenalkan Computational Thinking (CT) kepada siswa-siswi SM AN 7 Semarang berbasih problem solving; (2) Siswa membutuhkan pola pengajaran yang berorientasi pada problem solving sebagai bekal mereka memasuki dunia bisnis dan industri; dan (3) Memberikan pelatihan kepada guru-guru untuk menerapkan problem solving based pada pembelajaran di sekolah

Untuk melaksanakan kegiatan pelatihan tersebut, maka diperlukan perangkat sebagai berikut: (1) Kebutuhan hardware; spesifikasi hardware yang diperlukan untuk pelatihan ini adalah sebagai berikut: PC dengan processor minimal Core 2 duo, RAM minimal 1 GB dan Akses internet 10 Mbps; dan (2) Kebutuhan software; spesifikasi software yang dibutuhkan adalah Operating System Windows 8.

\section{Pelaksanaan Kegiatan}

Kegiatan pengabdian masyarakat dilaksanakan pada bulan November 2019 bertempat di Kampus Universitas Dian Nuswantoro. Siswa dan guru yang mendapatkan pelatihan problem solving dari SMAN 7 Semarang. Adapun tahapan pelaksanaan kegiatan adalah sebagai berikut:

Melakukan pre-test. Sebelum diberikan pelatihan siswa melakukan pre test terlebih dahulu, hasil dari pre-test menunjukkan bahwa kemampuan problem solving siswa SMAN 7 Semarang masih di bawah rata-rata standart nilai PISA di dunia.

Pelatihan dilaksanakan dengan 2 metode, yaitu teori dan praktikum. Secara teori, masing-masing peserta mendapatkan materi berupa arahan dari narasumber. Secara praktikum, peserta mendapatkan kesempatan untuk mempraktikkan secara langsung materi yang disampaikan oleh narasumber melalui PC atau gadget yang dioperasikan langsung oleh peserta pelatihan.

\section{HASIL DAN PEMBAHASAN}

Penyelenggaraan pelatihan yang diberikan bekerjasama dengan Bebras Indonesia. Peserta yang mengikuti pelatihan mengakses situs resmi Bebras yaitu http://bebras.or.id/. Adapun tampilan dari materi latihan Bebras Challenge adalah disajikan pada Gambar 1-7. 

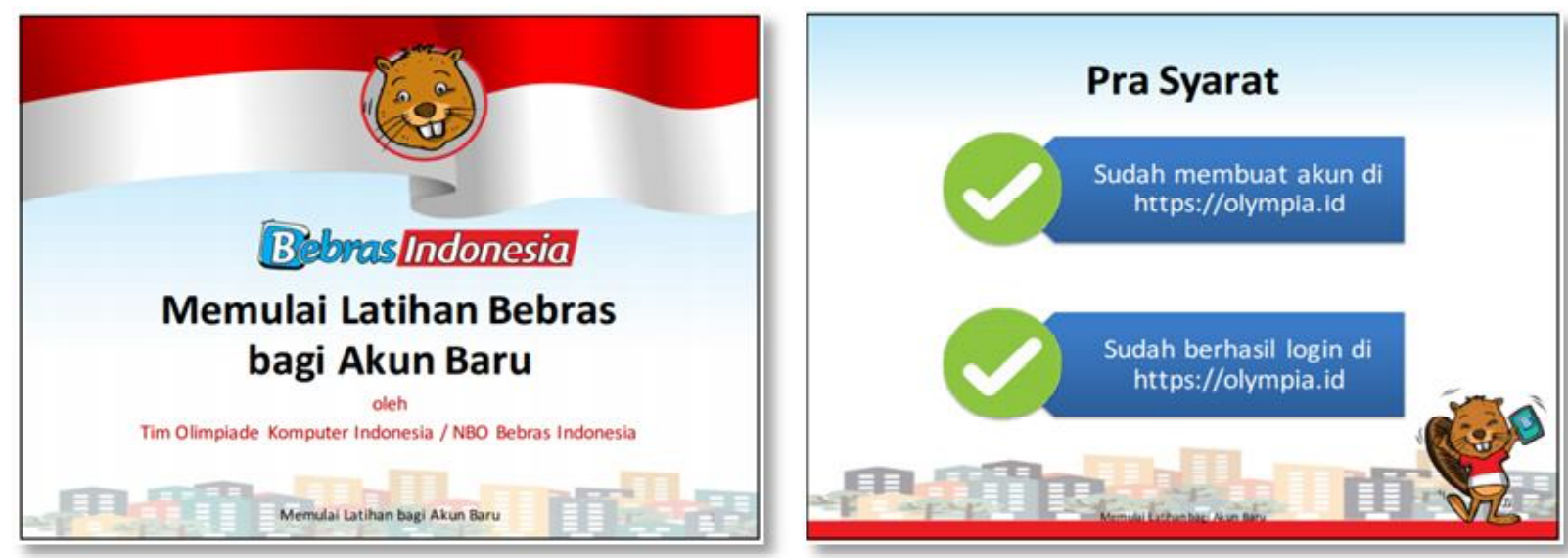

Gambar 1. Tampilan halaman muka untuk latihan Bebras dengan akun baru

Gambar 2. Tampilan halaman link registrasi akun Bebras Baru dan Login

Halaman muka menunjukkan identitas Bebras Indonesia, dimana peserta Bebras Challenge yang akan mengikuti pelatihan harus memiliki akun untuk dapaat login ke dalam sistem.

Terdapat 2 link pada halaman ini, bagi peserta yang belum memiliki akun dapat mendaftar terlebih dahulu dengan klik pada link registrasi. Dan peserta yang sudah memiliki akun dapat langsung klik link login.
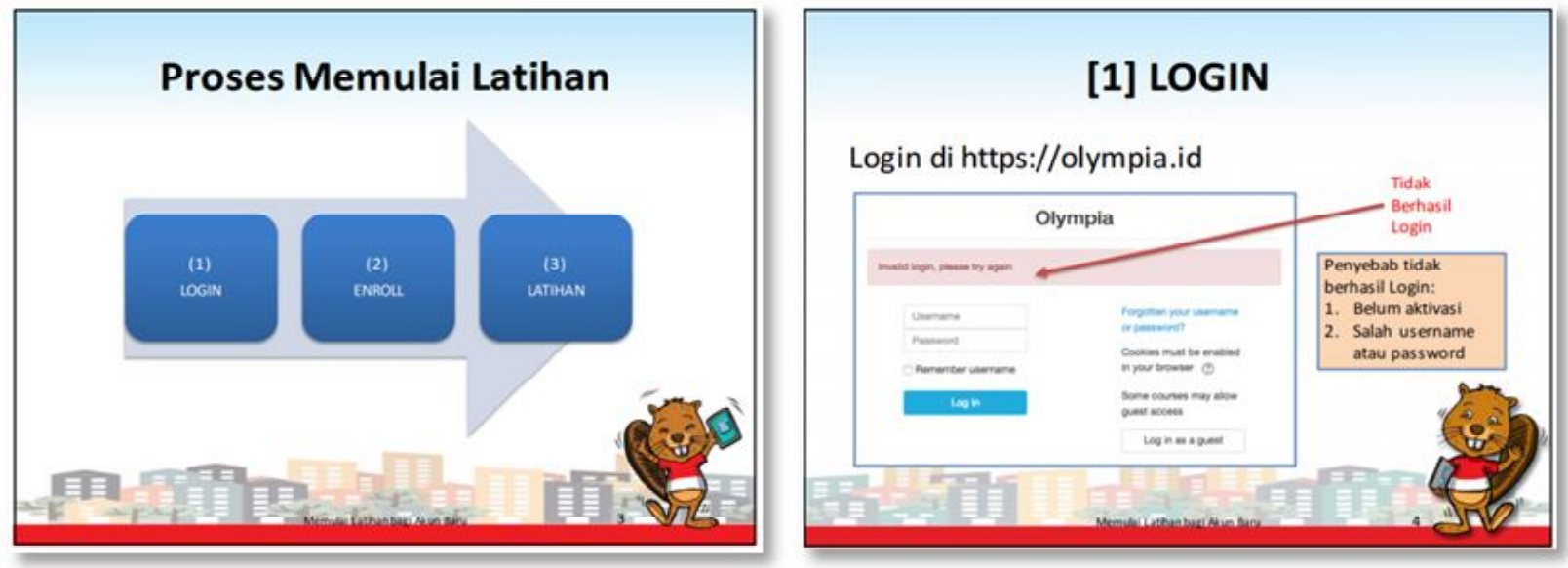

Gambar 3. Tampilan menu utama

Gambar 4. Halaman login

Setelah peserta berhasil melakukan login, akan tampil halaman utama dengan pilihan tomol menu seperti pada Gambar 3. Menu yang dapat dipilih yaitu: (1) Login; (2) Enroll ; dan (3) Latihan.

Peserta yang telah berhasil melakukan registrasi memerlukan aktifasi akun baru. Setiap peserta mendapatakn email dari Admin Olympia untuk mengaktifkan akun baru. Setelah mengaktivasi link yang ada di email tersebut, selanjutnya peserta akan masuk ke halaman login. Bagi peserta yang sudah 
ABDIMAS: Jurnal Pengabdian Masyarakat Universitas Merdeka Malang Volume 5, No 3, November 2020: 312-318

mengaktifkan akunnnya, maka dapat langsung klik tombol login pada menu (1) Login seperti yang ditampilkan pada Gambar 3.

Ada beberapa kendala pada waktu peserta melakukan Login, yang mengakibatkan gagal untuk masuk ke proses berikutnya. Kendala yang sering terjadi adalah peserta belum melakukan aktivasi melalui link yang dikirim Admin Olympia ke email mereka. Oleh karena itu, setelah mendaftar peserta harus memastikan bahwa akun yang mereka buat sudah di aktivasi sebelumnya. Jika peserta tidak melakukan aktivasi maka sistem tidak dapat mengenali akun baru tersebut. Sehingga password dan username yang diinputka oleh peserta pada saat login tidak dikenali oleh sistem.

Kendala lain yang sering terjadi adalah peserta lupa password atau username. Oleh karenanya peserta perlu mengulang untuk membuat password dan username baru dengan klik tombol link 'Lupa Password". Selanjutnya peserta akan dibawa ke halaman email untuk mengganti atau me-reset password akun lama password baru.
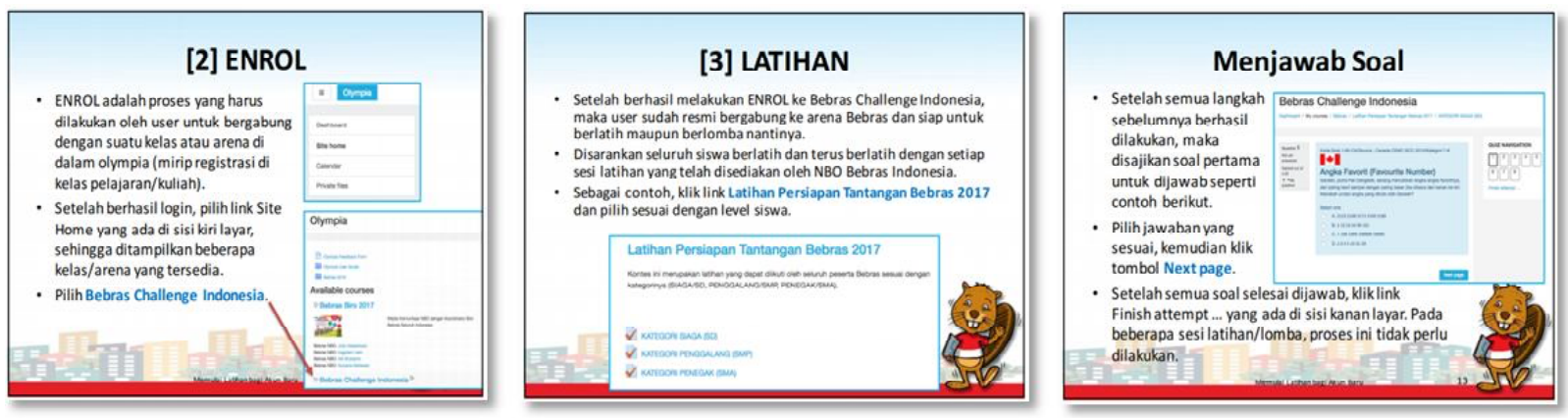

Gambar 5. Tampilan halaman Enroll

Gambar 6. Tampilan halaman Latihan

Gambar 7. Tampilan halaman Menjawab Soal

Setelah peserta berhasil login, akan ditampilkan link Site Home yang menampilkan kelas yang tersedia di halaman tersebut. Menu [2] Enrol ini diguankan peserta untuk memilih kelas yang akan diikuti. Selanjutnyan peserta dapat mengklik to mbol link Bebras Challenge Indonesia untuk menuju ke sesi berikutnya.

Setelah peserta berhasil memilih kelas pada menu [2] Enrol, maka peserta telah resmi bergabung dalam arena Bebras dan siap untuk berlatih atau berlomba di dalamnya. Setiap peserta diwajibkan untuk melakukan simulasi sebelum melakukan kompetisi. Sebagai contoh yaitu dengan melakukan latihan dengan mengklik tombol 'Latihan Persiapan Tantangan Bebras 2017' atau sesuai dengan pilihan masing-masing peserta.

Untuk menjawab soal, peserta memilih terlebih dahulu jawaban yang dianggap paling tepat kemudian klik 'next page'. Peserta diharapkan sudah membaca dengan cermat soal dan yakin dengan jawaban yang dipilih sebelum menekan tombol 'next page'. Karena peserta tidak dapat mengulang ke halaman soal sebelumnya jika merasa ada yang tidak tepat.

Pada pelatihan Bebras 2019 yang dilaksananakan di SMAN 7 Semarang diikuti oleh 8 siswa, seperti yang ditampilkan pada Tabel 1 . 
Tabel 1. Daftar Peserta Bebras 2019 dari Siswa SMA Negeri 7 Semarang

\begin{tabular}{lllll}
\hline \multicolumn{1}{c}{ Nama Siswa } & \multicolumn{1}{c}{ NIS } & Nama Akun & \multicolumn{1}{c}{ Email } & Kelas \\
\hline Bintang Laksamana Arsyad & 0040633927 & lakstar & bintangketu4811@gmail.com & X MIPA 2 \\
Ivan Naufal Rifqi Fauzi & 0034936759 & cetacea & rifqifauzi2003@gmail.com & X MIPA 2 \\
Satria Anadeus Davi Suseno & 0046722033 & deusz04 & deuscool123@gmail.com & X MIPA 2 \\
Sukra Rizky Putra Bimantara & 0042153261 & nyxtophiliax & bimantara657@gmail.com & X MIPA 2 \\
Rayhan Arya Syaidina & 0037913223 & rayhanarya & rayhanarya2165@gmail.com & X MIPA 1 \\
Radistya Ghaisan Pratama & 0034894102 & wazzo & radistyaghaisan@gmail.com & X MIPA 4 \\
$\begin{array}{l}\text { Dhimas Herdjuna Putro } \\
\text { Murachman }\end{array}$ & 0047278568 & rogue & dhimashpm17@gmail.com & X MIPA 4 \\
\hline
\end{tabular}
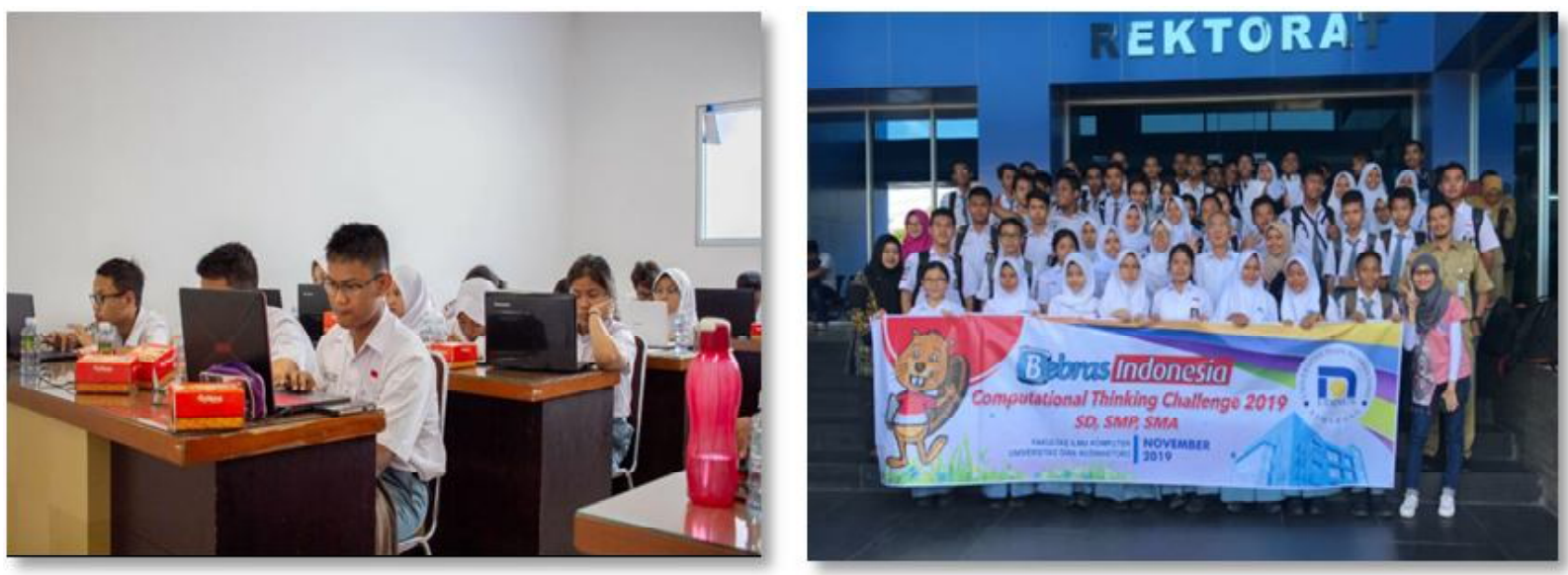

Gambar 8. Foto kegiatan bersama dengan murid-murid yang mengikuti Bebras Challenge.

Linier dengan bidang computational thingking, seluruh peserta yang mengikuti Bebras Challenge dari SMAN 7 Semarang adalah Siswa kelas X dari Jurusan MIPA. Capaian dari kegiatan Bebras Challenge ini diharapkan dapat menghasilakan kemampuan berpikir problem solving pada siswa di wilayah Semarang, khususnya SMAN 7 Semarang.

\section{SIMPULAN DAN SARAN}

Dari pemaparan hasil pengabdian masyarakat yang telah dilaksanakan di SM AN 7 Semarang maka tentang problem solving dapat disimpulkan bahwa: (1) Terjadi peningkatan cara berpikir berdasar problem solving siswa-siswi SMAN 7 semarang melalui hasil post test dengan Bebras Challenge; (2) Siswasiswi mampu memecahkan masalah dalam soal Bebras Challenge dengan mandiri; (3) Guru menerpakan problem solving based dalam proses belajar mengajar di sekolah.

\section{UCAPAN TERIMA KASIH}

Ucapan terima kasih kepada LPPM Universitas Dian Nuswantoro yang telah mendanai kegiatan program pengabdian kepada masyarakat tahun 2019. 
ABDIMAS: Jurnal Pengabdian Masyarakat Universitas Merdeka Malang

Volume 5, No 3, November 2020: 312-318

\section{DAFTAR PUSTAKA}

Arifin, S., Kartono, K., \& Hidayah, I. (2019). Analisis kemampuan pemecahan masalah pada model problem based learning disertai remedial teaching. Eduma: Mathematics Education Learning and Teaching, 8(1). https://doi.org/10.24235/eduma.v8i1.3355

Ayub, M., \& Karnalim, O. (2017). Edukasi berpikir komputasional melalui pelatihan guru dan tantangan bebras untuk siswa di Bandung pada tahun 2016. Prosiding Seminar Nasional Pengabdian Kepada Masyarakat 2017. https://doi.org/10.31227/osf.io/gwfv5

Chen, G., Shen, J., Barth-Cohen, L., Jiang, S., Huang, X., \& Eltoukhy, M. (2017). Assessing elementary students' computational thinking in everyday reasoning and robotics programming. Computers \& Education, 109, 162-175. https://doi.org/10.1016/j.compedu.2017.03.001

Dagiene, V., \& Futschek, G. (2013). Bebras, a contest to motivate students to study computer science and develop computational thinking. Proceedings of WCCE, 139-141.

Endah, S. N., Sarwoko, E. A., Bahtiar, N., Wibowo, A., \& Kurniawan, K. (2020). Pembinaan pola pikir komputasi dan informatika pada siswa Sekolah Dasar. E-Dimas: Jurnal Pengabdian kepada Masyarakat, 11(1), 1-6.

Maulidya, A. (2018). Berpikir dan problem solving. Ihya al-Arabiyah: Jurnal Pendidikan Bahasa dan Sastra Arab, 4(1).

Mayer, R. E. (1992). Thinking, problem solving, cognition. WH Freeman/Times Books/Henry Holt \& Co.

PISA: Programme for International Student Assessment. (2017). OECD Education Statistics. https://doi.org/10.1787/data-00365-en

Wing, J. M. (2006). Computational thinking. Communications of the ACM , 49(3), 33-35. https://doi.org/10.1145/1118178.1118215

Wiradharma, G., Arisanty, M., Saputra, A. H., Anam, K., \& Robiansyah, A. (2020). The video online learning guides for beginner college students. Dinamisia: Jurnal Pengabdian Kepada M asyarakat, 4(3), 391-397. https://doi.org/10.31849/dinamisia.v4i3.4378 